Research Article

\title{
Evaluation of analgesic activity of aqueous extract of leaves of hibiscus sabdariffa in albino rats
}

\author{
Soumya Basavaraj Patil*, Sanappa Rambhimaiah, Prabhakar Patil
}

Department of Pharmacology, Navodaya Medical College, Hospital and Research Centre, Raichur, Karnataka, India

Received: 15 March2016 Accepted: 15 April 2016

\section{*Correspondence to:}

Dr. Soumya Basavaraj Patil, Email:sou_doc@yahoo.co.in

Copyright: (C) the author(s), publisher and licensee Medip Academy. This is an openaccess article distributed under the terms of the Creative Commons Attribution NonCommercial License, which permits unrestricted noncommercial use, distribution, and reproduction in any medium, provided the original work is properly cited.

\begin{abstract}
Background: Analgesia and inflammation continues to be an area of great interest for research, probably due to the non-availability of a safer and more effective analgesic and anti-inflammatory agent. This has led to increase in demand for natural products with analgesic and anti-inflammatory activity having fewer side effects. Non-steroidal anti-inflammatory drugs (NSAIDs) such as indomethacin are used in the treatment of inflammation, fever and pain. However, NSAIDs cause gastric damage as a major adverse reaction. In this study, the analgesic and anti-inflammatory activity of aqueous extract $H$. sabdariffa Linn was studied using hot plate method in albino rats.

Methods: In this study, analgesic activity of $H$. sabdariffa was studied and compared with standard drug, indomethacin using Hot plate method. Aqueous extract of leaves of $H$. sabdariffa $(200 \mathrm{mg} / \mathrm{kg}$ or $400 \mathrm{mg} / \mathrm{kg})$ and indomethacin $(25 \mathrm{mg} / \mathrm{kg}$ ) were used to separate groups of rats and reaction time was measured at 20,60, 90 minutes and compared with control group.

Results: All the test groups showed significant $(\mathrm{P}<0.05)$ analgesic effect in increasing the reaction time in hot plate method during the entire test period of 90 minutes.

Conclusions: $H$. sabdariffa possesses significant analgesic activity probably due to presence of flavonoids and organic acids like ascorbic acid and citric acid as well as polysaccharides reported to be present in this plant.
\end{abstract}

Keywords: H. sabdariffa Linn, Analgesic, Indomethacin, Albino rats

\section{INTRODUCTION}

The task of medicine is to preserve and restore health and to relieve suffering. Understanding pain is essential to both these goals. Since history, pain has been treated by psychologic techniques, physical methods (surgical intervention, electrical stimulation, pressure, cold, heat, counter-irritation, acupuncture etc.,) and by drugs. ${ }^{1}$ The ideal treatment for any pain is to remove the cause; thus, diagnosis should always precede treatment planning.

Present day analgesics have many side effects, like gastrointestinal bleeding, analgesic nephropathy, cardiovascular accidents etc. They can also be fatal in overdose as quite a few analgesics have very narrow therapeutic window, especially with opioids. They also have high risk of abuse. Many non-steroidal antiinflammatory drugs (NSAID's) like aspirin, phenylbutazone, indomethacin etc. are in clinical use but, all these are not completely devoid of adverse effects. ${ }^{2}$

Use of plant products is increasing in many segment of the population. ${ }^{3}$ At present, thousands of plant metabolites are being successfully used for the treatment of variety of diseases. According to an estimate, $80 \%$ of the world's population relied upon plants for their medication. ${ }^{4}$ The use of the medicinal plants is increasing in many countries where $35 \%$ of drugs contain natural products. As a result of adverse effects such as gastric lesions caused by non-steroidal anti-inflammatory drugs (NSAID), tolerance and dependence induced by opiates, the use of these drugs as analgesic agents have not been 
successful in all cases. ${ }^{5,6}$ Moreover, synthetic drugs are very expensive to develop. It is therefore essential that efforts should be made to introduce new medicinal plants to develop cheaper drugs.

The Hibiscus sabdariffa is a species of Hibiscus, commonly known as Jasvand. ${ }^{7}$ The plant is native to tropical central or West Africa but well cultivated in tropical Asia, Northern Australia and many other tropical countries. It is an annual or perennial herb or woody based subshrub, growing to 7-8 feet tall. The leaves are deeply 3 to 5 lobed, $8-15 \mathrm{~cm}$ long, arranged alternately on the stems. It takes about six months to mature.

Hibiscus is an important medicinal plant represented by 250 species. Hibiscus sabdariffa L. (Malvaceae), is an annual shrub and commonly used to make beverages. One study showed, the calyces have been used in folk medicines and claimed effective as diuretics, stomachic, aphrodisiac, antiseptic, astringent, cholagogue, digestive, sedative, laxative, antimicrobial or as remedy for pyrexia, abscesses, heart ailments and hypertension. ${ }^{8}$

Other studies say that $H$. sabdariffa $L$. possess biological activities like antihypertensive, anticancer, antihyperlipidemic, antioxidant, anticonvulsant, anxiogenic, CNS-depressant, serotoninergic activities, reducing oxidative liver damage, anti-inflammatory, and hypoglycemic activity. ${ }^{9}$ The antipyretic, analgesic and anti-inflammatory activity of ethanol and aqueous extract of red calyces of $H$. sabdariffa has also been reported. ${ }^{10}$

The plant has protective activities against tert-butyl hydroperoxide and Lipopolysaccharide induced hepatic damage in rats. ${ }^{11-13}$ The antipyretic, analgesic and antiinflammatory activity of ethanol and Aqueous extract of red calyces of $H$. sabdariffa has also been reported. ${ }^{10}$

The present study is therefore undertaken to evaluate the analgesic and anti-inflammatory effect of aqueous extract of leaves of Hibiscus sabdariffa L . in albino rats.

\section{METHODS}

The study was carried out in the post graduate research laboratory, department of pharmacology, Navodaya Medical College, Raichur, Karnataka, India.

Animals used in the present experiment were albino rats weighing 150-250 g of either sex, obtained from national institute of nutrition, Hyderabad, maintained at air conditioned central animal house, Navodaya Medical College, Raichur, Karnataka, India under suitable conditions of housing, temperature, ventilation and nutrition as per CPCSEA guidelines. Ethical clearance from the institutional animal ethical committee was obtained. All the drugs were administered orally with the help of a sterile, nontoxic tube made up of polyvinyl chloride.

\section{Preparation of extract}

The whole fresh leaves of $H$. sabdariffa were collected, air dried under shade for two days and then powdered. $100 \mathrm{~g}$ of powder was taken and kept for maceration for two days in $1000 \mathrm{ml}$ of distilled water, frequently stirred and about 5 to 10 drops of chloroform per day was added. Then it was filtered using a muslin cloth, so as to remove insoluble material. The filtrate was again filtered by double layered muslin cloth and then poured in ordinary, cleaned and already weighed plates for drying. Finally, the chocolate-coloured semisolid residue was weighed and pooled together in an air and water proof container kept in a refrigerator at 40c. From this fresh preparations were made whenever required.

\section{Hot plate analgesiometer}

For analgesic activity. (Eddy's hot plate method). ${ }^{14}$

This protocol describes the use of a hot plate (INCO, Chennai, India) to measure the potential analgesic effect of test compound to an acute thermal stimulus. The hot plate consists of an electrically heated surface, the temperature of which is maintained at $55^{\circ} \mathrm{C}$ to $56^{\circ} \mathrm{C}$.

Healthy young albino rats of either sex weighing 150-250 $\mathrm{g}$ and showing a normal reaction time of 5 seconds were used for the study. They were divided into four groups of six animals each.

Group I: Control rats-received vehicle only (distilled water)

Group II: Standard rats-received Indomethacin $25 \mathrm{mg} / \mathrm{kg}$ Group III: Test rats-received HS $200 \mathrm{mg} / \mathrm{kg}$

Group IV: Test rats-received HS $400 \mathrm{mg} / \mathrm{kg}$

The paws of mice and rats are very sensitive to heat at temperatures which are not damaging the skin. The responses are jumping, withdrawal of the paws and licking of the paws. The time until these responses occur is prolonged after administration of centrally acting analgesics, whereas peripheral analgesics of the acetylsalicylic acid or phenyl-acetic acid type do not generally affect these responses. The rats were placed individually on the hot plate and the reaction time between placing the animal on the hot plate and licking of fore or hind limb (paw response) or the jump response recorded by a stop-watch. In order to avoid thermal injury to the paws a cut off time of 30 secs was followed. The latencies were recorded before and after 20, 60 and 90 mins following drug administration. The results were expressed as mean \pm SEM and data analysed statistically.

\section{RESULTS}

\section{Hot plate method}

The mean reaction time at different time intervals i,e at 20, 60, and 90 minutes of each group is represented in (Table 1 and Figure 1). 
Table 1: Effect of aqueous extract of leaves of Hibiscus sabdariffa on reaction time in hot plate method.

\begin{tabular}{|c|c|c|c|c|c|}
\hline \multirow[t]{2}{*}{ Treatment group (dose) } & \multirow{2}{*}{$\begin{array}{l}\text { Pre-drug reaction time in sec } \\
(\text { mean } \pm \text { SD })\end{array}$} & \multicolumn{3}{|c|}{$\begin{array}{c}\text { Post drug time ( minutes ) } \\
\text { Reaction time in sec }(\text { mean } \pm \text { SD })\end{array}$} & \multirow[t]{2}{*}{ p value } \\
\hline & & 20 & 60 & 90 & \\
\hline Control group (D/W $2 \mathrm{ml} / \mathrm{kg}$ ) & $3.33 \pm 0.408$ & $3.33 \pm 0.258$ & $3.58 \pm 0.492$ & $3.42 \pm 0.376$ & 0.660 \\
\hline Group 2 (IND 25 mg/kg) & $3.50 \pm 0.632$ & $4.42 \pm 0.861$ & $8.58 \pm 1.744$ & $11.08 \pm 1.686$ & 0.00001 \\
\hline Group 3 (HS 200 mg/kg) & $3.17 \pm 0.516$ & $4.00 \pm 0.447$ & $5.42 \pm 1.021$ & $7.83 \pm 1.571$ & 0.00001 \\
\hline Group 4 (HS 400 mg/kg) & $3.5 \pm 1.320$ & $4.50 \pm 0.894$ & $6.50 \pm 1.378$ & $9.33 \pm 1.366$ & 0.00001 \\
\hline
\end{tabular}

Results expressed as mean $\pm \mathrm{SD}, \mathrm{n}=6, \mathrm{P}$ value $<0.05$ is significant; $<0.001$ is highly significant. Fischer exact test followed by ANOVA.

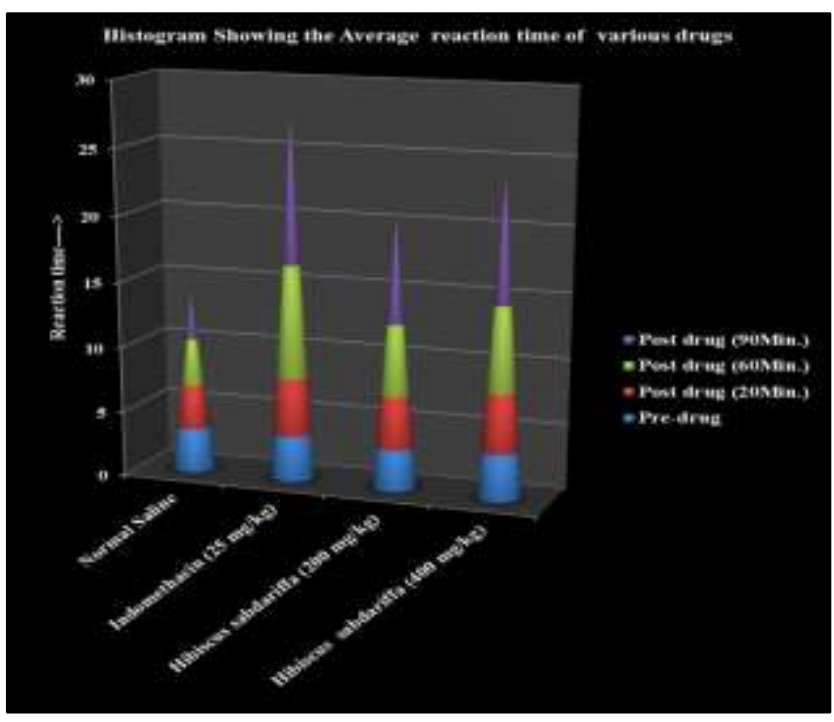

Figure 1: Effect of aqueous extract of leaves of $\boldsymbol{H}$. sabdariffa and indomethacin at various time intervals on Hot plate method in albino rats.

\section{Effect of distilled water treatment}

In the distilled water treated animals there was no significant change ( $\mathrm{P}$ value $>0.05$ ) in reaction time during the entire test period.

\section{Effect of Indomethacin $25 \mathrm{mg} / \mathrm{kg}$ treatment}

In indomethacin treated animals there was highly significant increase ( $\mathrm{P}$ value $<0.001)$ in the reaction time during the entire test period.

\section{Effect of HS $200 \mathrm{mg} / \mathrm{kg}$ treatment}

In HS $200 \mathrm{mg} / \mathrm{kg}$ treated animals there was highly significant increase $(\mathrm{P}$ value $<0.001)$ in the reaction time during the entire test period.

\section{Effect of HS $400 \mathrm{mg} / \mathrm{kg}$ treatment}

In HS $400 \mathrm{mg} / \mathrm{kg}$ treated animals there was highly significant increase ( $\mathrm{P}$ value $<0.001$ ) in the reaction time during the entire test period.
HS $400 \mathrm{mg} / \mathrm{kg}$ was found to be better than HS $200 \mathrm{mg} / \mathrm{kg}$ during entire test period of 90 minutes. However, both HS $200 \mathrm{mg} / \mathrm{kg}$ and HS $400 \mathrm{mg} / \mathrm{kg}$ were not found to be better than the Standard drug i,e Indomethacin during entire test period of 90 minutes.

\section{DISCUSSION}

Hibiscus sabdariffa is known for delicacy and also for medicinal properties. I Progress in medicinal plant research have undergone a phenomenal growth during last two decades. Worldwide trend towards the utilization of natural plant remedies has created an enormous need for information about the properties and uses of medicinal plants as antitumor, analgesic, insecticides. Besides medicines, plants provides thousands of novel compounds, such as fragrance, flavourings, dyes, fibers, foods, beverages, building materials etc.

The present study was undertaken to investigate the analgesic activity of aqueous extract of leaves of $H$. sabdariffa in albino rats. The Hot plate method used is sensitive to centrally acting analgesic drugs i,e mediated at supraspinal level. ${ }^{15,16}$ Results of the present study in comparison with control clearly indicate that the $H$. sabdariffa showed significant analgesic activity. Similarly results of the present study in comparison with standard drug i,e Indomethacin indicate that the $H$. sabdariffa were almost as good as indomethacin in increasing the mean reaction time in albino rats in Hot plate method. The observation in the present study is in close agreement to the previous worker and it is concluded that the aqueous and alcoholic extracts of other species of hibiscus possess significant analgesic activity in wistar albino rats. ${ }^{17}$

The analgesic effect observed with $H$. sabdariffa could be attributed to the presence of flavonoids and organic acids like ascorbic acid and citric acid as well as polysaccharides reported to be present in this plant. ${ }^{18,19}$ Previous studies reported the isolation of three polysaccharides from $H$. sabdariffa that showed immunemodulating effects. ${ }^{20}$ The exact role of each one of these components in the pharmacological activity of 
H. sabdariffa requires further studies and proper extraction procedures.

Funding: No funding sources

Conflict of interest: None declared

Ethical approval: The study was approved by the Institutional Ethics Committee

\section{REFERENCES}

1. Fishman S, Ballantyne J, Rathmell JP, Bonica JJ. Bonica's management of pain. $4^{\text {th }}$ ed. Baltimore, MD: Lippincott, Williams and Wilkins; 2010:xxxiii:1661.

2. Laurence LB, Bruce AC, Björn CK. Goodman and Gilman's The pharmacological basis of therapeutics. $12^{\text {th }}$ ed China: McGraw-Hill Publishers; 2011.

3. Eisenberg DM, Kessler RC, Foster C. Unconventional medicine in the United States: prevalence, costs and patterns of use. N Eng J Med. 1993;328:246-52.

4. Rakh MS, Chaudhari SR. Evaluation of CNS depressant activity of $\langle\mathrm{I}\rangle$ Momordica dioica Roxb $</ I>$ willd fruit pulp. Int $\mathrm{J}$ Pharm Sc. 2010;2(4):124-6.

5. Dharmasiri JR, Jayakody AC, Galhena G, Liyanage SSP, Ratnasooriya WD. Anti-inflammatory and analgesic activities of mature fresh leaves of Vitex negundo. J Ethnopharmacol. 2003;87:199-206.

6. Park JH, Son KH, Kim SW, Chang HW, Bae K, Kang SS, Kim HP. Anti-inflammatory activity of Synurus deltoids. Phytother Res. 2004;18:930-3.

7. Kirtikar KR, Mayor, Basu BD. Indian medicinal plants. Intenational book distributor. 1987;1:335-6.

8. Perry JM. Medicinal plants of East and Southeast Asia: attributed properties and uses. MIT Press, Cambridge, MA. 1980;334-60.

9. Mahadevan N, Shivali, Kamboj P. Hibiscus sabdariffa L.-An overview. Natural Product Radiance. 2009;8(1):77-83.
10. Reanmongkol W, Itharat A. Antipyretic activity of the extracts of Hibiscus sabdariffa calyces L. in experimental animals. Songklanakarin J Sci. Technol. 2007;9:29-38.

11. Tseng TH, Kao CY, Chu CY, Chou FP, Lin Wu HW, Wang CJ. Protective effects of dried flower extracts of Hibiscus sabdariffa L. against oxidative stress in rat primary hepatocytes. Food Chem. Toxicol. 1997;35:1159-64.

12. Liu CL, Wang JM, Chu CY. In vivo protective effect of protocatechuic acid on tertbutylhydroperoxideinduced rat hepatotoxicity. Food Chem Toxicol. 2002;40:635-41.

13. Lin WL, Hsieh YJ, Chou FP, Wang CJ, Cheng MJ, Tseng TH. Hibiscus protocatechuic acid inhibits lipopolysaccharide induced rat hepatic damage. Arch. Toxicol. 2003;77:42-7.

14. Hosseinzadeh H, Ramezani M, Salmani G. Antinociceptive, anti-inflammatory and acute toxicity effects of Zataria multiflora Boiss extracts in mice and rats. J Ethano pharmacol. 2000;73:379-85.

15. Prado WA, Tonussi CR, Rego EM, Corrado AP. Antinociception induced by intraperitoneal injection of gentamicin in rats and mice. Pain. 1990;4:365-71.

16. Gupta M, Mazumder UK, Kumar RS, Gomathi P, Rajeshwar Y, Kakoti BB, et al. Anti-inflammatory, analgesic and antipyretic effects of methanol extract from bauhinia racemosa stem bark in animal models. J Ethnopharmacol. 2005;98:267-73.

17. Ghosh MN. Fundamentals of experimental pharmacology. $2^{\text {nd }}$ edn. Scientific book agency Calcutta; 144.

18. Garbor M. The anti-inflammatory action of flavonoids. Budapest, hungary: akademiai kiado. 1972;24.

19. Parmar NS, Ghosch MN. Current trends in flavanoids research. Ind J Pharmacol. 1980;12:213-8.

20. Muller BM, Franz G. Chemical structure and biological activity of polysaccharides from Hibiscus sabdariffa. Planta Med. 1992;58(1):60-7.

Cite this article as: Patil SB, Rambhimaiah $\mathrm{S}$, Patil P. Evaluation of analgesic activity of aqueous extract of leaves of hibiscus sabdariffa in albino rats. Int $\mathrm{J}$ Basic Clin Pharmacol 2016;5:910-3 